http://dx.doi.org/10.1590/1678-4162-8513

Arq. Bras. Med. Vet. Zootec., v.68, n.4, p.853-857, 2016

\title{
Brucella spp. in equines slaughtered in the south region of Brazil
}

[Anticorpos contra Brucella spp. em equídeos da região Sul do Brasil abatidos em matadouro-frigorífico]

\author{
R.F. Santos, G.C.P. Silva, N.A. Assis, L.A. Mathias
}

Universidade Estadual Paulista "Júlio de Mesquita Filho" - UNESP - Jaboticabal, SP

\begin{abstract}
Bacteria of the genus Brucella are widespread in many countries. These microorganisms can infect humans and many wild and domestic animal species. These bacteria have zoonotic potential, and can cause economic and public health problems since they can be transmitted by direct contact with sick animals, through consumption of contaminated milk, raw meat and its derivatives (Soares et al., 2015). Brucellosis is considered a chronic evolving disease, unusual in horses, predominantly caused by Brucella abortus. However, it is not characterized by reproductive disorders in horses, but primarily by abscess in the cervical region, bursa, tendons, and joints. Transmission is likely to occur via ingestion of contaminated water and pastures, especially in areas endemic for bovine brucellosis (Ribeiro et al., 2008). The slaughterhouse is a strategic point for obtaining information about the animal and animal products, edible or not. This study investigated the presence of anti-Brucella spp. immunoglobulins in the serum samples from horses slaughtered in a slaughterhouse in southern Brazil, to estimate the frequency of Brucella spp. antibodies and determine the spatial distribution of the cases.
\end{abstract}

Keywords: equine, abattoirs, brucellosis, equine, fluorescence polarization, complement fixation

\section{RESUMO}

Objetivou-se investigar a presença de imunoglobulinas anti-Brucella spp. em amostras de soros sanguíneos de equídeos abatidos em matadouro-frigorífico, sob Serviço de Inspeção Federal, localizado na região Sul do Brasil. Utilizaram-se 767 amostras de sangue de equídeos adultos abatidos no período de abril a maio de 2013. Os animais foram provenientes de 45 municípios dos estados do Rio Grande do Sul, Santa Catarina e Paraná. Para diagnóstico, foram utilizados os testes do antígeno acidificado tamponado (AAT), sendo os resultados positivos confirmados pelos testes de polarização fluorescente (TPF), reação de fixação de complemento (RFC) e 2-mercaptoetanol (2-ME). Foram sororreagentes no AAT 65 (8,47\%) animais. Destes, apenas dois $(3,07 \%)$ foram positivos também na RFC e três $(4,62 \%)$ animais foram positivos no TPF. Apesar da baixa frequência de animais positivos para Brucella spp., pode-se afirmar que a infecção em equinos está presente na área estudada, o que é demonstrado pela presença de animais sororreatores. No âmbito da saúde animal, pública e ocupacional, sugere-se a atenção a essa doença, visando diminuir o risco de infecção.

Palavras-chave: equinos, abatedouro, brucelose, polarização fluorescente, reação de fixação de complemento

\section{INTRODUCTION}

For the calculation of the sample size, by means of the formula recommended by Thrusfield (2005), an expected prevalence of $2 \%$, a sampling error of $1 \%$, and a confidence level of $95 \%(\mathrm{z}=1.96)$ were considered, resulting in a minimum number of animals to be examined

Recebido em 15 de junho de 2015

Aceito em 11 de fevereiro de 2016

E-mail: renatafdsantos@hotmail.com equal to 753. A total of 767 blood samples were collected from adult horses (762 horses and five mules), males $(\mathrm{n}=407)$ and females $(\mathrm{n}=360)$, slaughtered in a slaughterhouse inspected by the Federal Inspection Service, in the Southwest region of Rio Grande do Sul. Blood samples were collected from horses slaughtered during the period from April to May 2013. These animals originated from 45 counties in Rio Grande do Sul, Santa Catarina, and Paraná. 
The horses from Rio Grande do Sul came from 37 municipalities: Alegrete, Bagé, Caçapava do Sul, Cacequi, Canguçu, Capão Cipó, Cristal, Cruzeiro do Sul, Dom Pedrito, Encruzilhada do Sul, Itacurubi, Itaqui, Lavras do Sul, Maçambara, Pinheiro Machado, Piratini, Pelotas, Quaraí, Rosário do Sul, Santa Cruz do Sul, Santa Maria, Santa Vitória do Palmar, Santana da Boa Vista, Santana do Livramento, Santiago, Santo Ângelo, Santo Antônio das Missões, São Borja, São Francisco de Assis, São Gabriel, São Lourenço do Sul, Taquari, Unistalda, Vacaria, and Vila Nova do Sul. The horses from Santa Catarina were from Bandeirante, Lages, Saltinho, and São Miguel do Oeste. Finally, the horses from Paraná were from Ampére, Nova Laranjeiras, Paulo Frontin, and São Mateus do Sul. The blood samples were collected during bleeding using disposable tubes, in the slaughtering process. After obtaining the serum, the aliquots were transferred to microtubes, tagged and stored at $20^{\circ} \mathrm{C}$ until use. The rose bengal plate test (RBPT) was used in the diagnosis, and the positive results were confirmed by the fluorescence polarization assay (FPA), complement fixation (CFT) and 2mercaptoethanol (2-ME) tests.

The Rose Bengal Plate (RBPT) screening test was performed following the standard technique (Alton et al., 1988). The positive RBPT results were confirmed by the fluorescence polarization assay (FPA). Also, blood samples from animals with lesions suggestive of brucellosis were also submitted to FPA whether reactive to RBPT or not. The test was performed according to the methodology described by Nielsen et al. (1996), using the "Brucella abortus Antibody Test Kit" (Diachemix, USA). The results were interpreted following the manufacturer recommendations. Sample measurements were compared to the negative control serum and classified as follows, up to $9.9 \mathrm{mP}$ (milipolarization units), negative for brucellosis; between 10.0 and $20.0 \mathrm{mP}$, suspected of brucellosis; and greater than $20 \mathrm{mP}$, positive.

Every sample positive for RBPT was also submitted to the complement fixation test (CFT). The titer was given by the reciprocal of the highest serum dilution with at least $25 \%$ complement fixation, and a positive serum had at least $25 \%$ of complement fixation in the $1: 4$ dilution. Serum samples positive for RBPT, CFT, and FPA, were also tested by the 2mercaptoethanol test (2-ME) (Alton et al., 1988).

Microsoft Excel, version 2007, was used to construct the database, tables, and graphs. Each serum sample had information regarding the city of origin, date of collection, sex, species, and the results of RBPT, CFT, FPA and 2-ME tests. The maps were produced by the MapInfo $\AA$ program. The 95\% confidence intervals (CI) of the observed frequencies of reactive animals were calculated (Thrusfield, 2005).

Of the total, $65(8.47 \%)$ animals were reactive to RBPT. Of these, only two (3.07\%) were also positive for CFT, with titers of 16 and $\geq 128$. Three $(4.62 \%)$ horses were positive for FPA. Of these three samples, one sample with a diverging result for the CFT test was subjected to 2-ME test, and the result was inconclusive.

Thus, in the present study, only two animals, one mare and one horse $(0.26 \%$; $95 \%$ CI: $0.07 \%$ - $0.95 \%$ ), were positive for all tests (RBPT, FPA, and CFT). The mare from Santa Vitória do Palmar, Rio Grande do Sul, had titer $\geq 128$ to CFT, and the horse from Ampére, Paraná, had titer 16 . This low frequency $(0.26 \%)$ is common and confirms that horses are not natural hosts of the Brucella genus. However, eventually, a serological response against this microorganism was found in this species.

Equine brucellosis is known to occur primarily in areas where bovine brucellosis is endemic. The spatial distribution of the two cases of brucellosis in horses in this study coincides with areas where bovine brucellosis also occurs, as shown by Dias et al. (2009) for Paraná (Figure 1), and Marvulo et al. (2009) for Rio Grande do Sul (Figure 3).

Paraná is divided in two distinct regions: Northwest (producer areas 1 and 2), with highest prevalence, and South (producer areas 3 to 7), with lower prevalence (Dias et al., 2009). The municipality of Ampére that had one reactive horse is in Southwestern Paraná (Figure 2) and coincides with area 7 (Figure 1), which according to Dias et al. (2009) had a prevalence of $1 \%$ of infected herds and $2.20 \%$ of seropositive animals. 


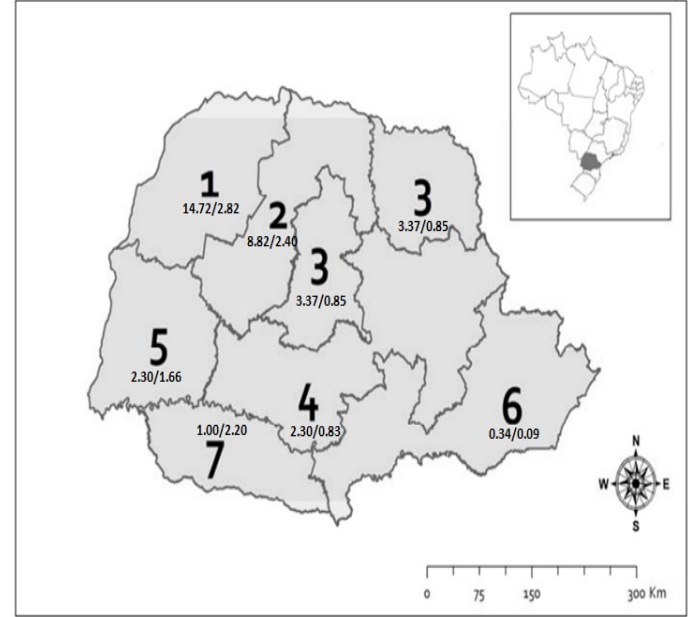

Figure 1. Map of Paraná divided into producer areas showing the prevalence of brucellosis foci (left) and seropositive females (right) (Dias et al.,2009).

Epidemiological surveillance of other species is recommended due to the low prevalence of the disease in this area, and this study showed that the disease is present in other animal species in area 7. Ampére is close to the border with Santa Catarina, where only residual foci of brucellosis have been reported. Thus, activities such as buying, selling and transporting different species animals, for agribusiness fairs and slaughterhouses between these states must be carefully controlled so that Santa Catarina can continue to eradicate the disease in the state.

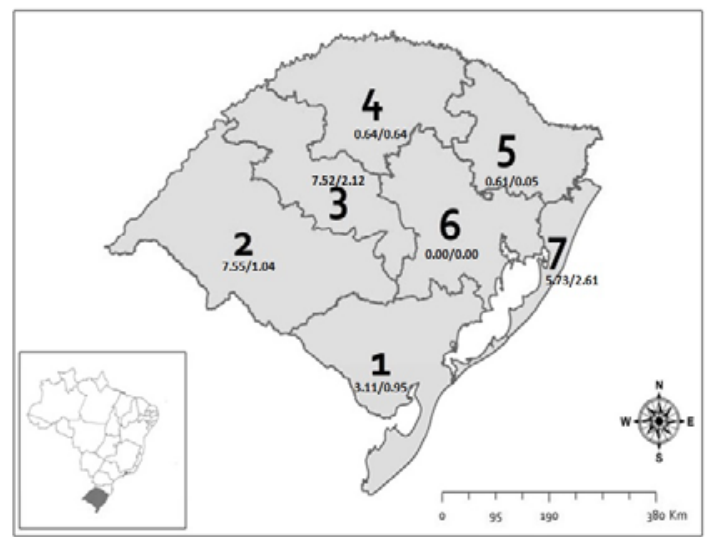

Figure 3. Map of Rio Grande do Sul showing livestock producing areas, with prevalence of brucellosis foci (left) and seropositive females (right) (Marvulo et al. 2009).

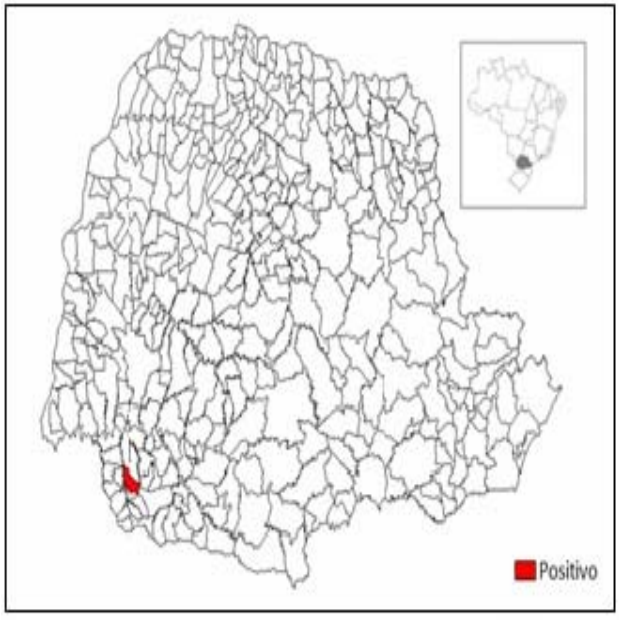

Figure 2. County of the animal that tested positive for brucellosis in Paraná.

In Rio Grande do Sul, according to the study by Marvulo et al. (2009), the south-southeast (producer areas 1, 2, 3 and 7) region has a high prevalence of brucellosis in cattle and buffaloes while the northern region (producer areas 4, 5 and 6) has low prevalence.

The positive animal from Santa Vitória do Palmar (Figure 4), Rio Grande do Sul, is from the producer area 1 according to the study by Marvulo et al. (2009). The $3.01 \%$ prevalence of bovine brucellosis foci and $0.95 \%$ seropositive animals are among the highest prevalence areas in the state.

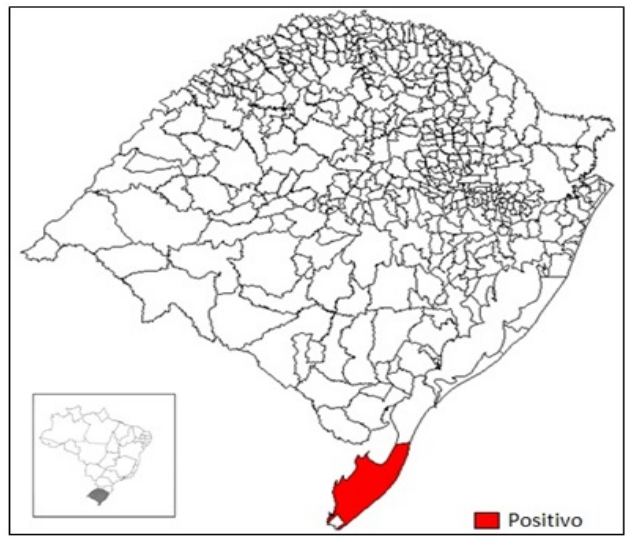

Figure 4. County of the animal that tested positive for brucellosis in Rio Grande do Sul. 
The maps show that the disease in horses occurred in areas where bovine brucellosis is also present. As the horses are often bred in the same habitat, dividing pastures and troughs with cattle, the direct or indirect contact between the two species allows the transmission of the etiological agent.

A direct comparison between the frequency of positive animals (horses, donkeys and mules) in the present study with that found in serological surveys in Brazil is difficult because there is no standardization of diagnostic tests for brucellosis in horses, unlike cattle. Dorneles et al. (2013) also reported this difficulty, adding that differences in sampling designs, serological tests, diagnostic points, sampling size and representativeness of the sample make it difficult to compare results.

This fact has also been observed in the present study. The RBPT test had a large number of false-positive animals since the confirmatory FPA showed that only three animals were, in fact, positive, and the CFT and 2-ME test results did not repeat.

Thus, even with the lack of standardization among these tests, a few studies have reported the presence of antibodies against this microorganism in Brazil. Several authors found low prevalence of positive animals, albeit higher than this study. In Mossoró, Rio Grande do Norte, Dorneles et al. (2013) reported four $(1.76 \%)$ animals positive for antibodies to Brucella spp., confirmed by the 2-ME test. Furquim et al. (2012) investigated 107 blood samples of horses and mules and reported that the screening test (RBPT) resulted in 43 positive and 54 negative samples while the confirmatory test (2-ME) showed that $5(4.67 \%)$ animals were positive and $10(9.35 \%)$, inconclusive. Junqueira Júnior et al. (2015) estimated the seroprevalence of brucellosis in working equines of cattle farms in Minas Gerais, Brazil, and reported that the prevalence of antibodies against smooth Brucella spp. was $1.37 \%$, resulting in a prevalence of $4.28 \%$ of herds with infected animals.

Other authors also reported that either no horse was positive for brucellosis or a very low frequency, similar to the present study. In Paraíba, there were no positive animals among
123 work horses according to confirmatory tests (Antunes et al., 2013). Chaves et al. (2015) investigated 415 horses belonging to "Baixadeiro" racial grouping, in Baixada Maranhense, and only four $(0.96 \%)$ were positive for brucellosis confirmed by $2 \mathrm{ME}$.

Therefore, the available data show that the disease is present in horses in Brazil, due to the presence of serum reactive animals. The numbers suggest a low prevalence in cattle in the south and, it is, therefore, necessary to perform surveillance of the disease in other species, such as horses, to eradicate the disease effectively. Although horses are not reservoirs of the causative agent, once infected, they could, at least theoretically, transmit the infection to other species.

Furthermore, the presence of animals seropositive for brucellosis in this study suggests the need to conduct further investigations to elucidate the epidemiological situation of horses slaughtered in Brazil, since there are occupational groups that are often at risk of infection, such as butchers, veterinarians, and producers. Moreover, because the animals destined for slaughtering are removed from work and reproduction, they often end up living in constant contact with humans, through activities such as animal-assisted therapy, sightseeing, and agricultural fairs, and could end up transmitting the pathogen to humans and other animal species, thus favoring the spread of the disease.

\section{REFERENCES}

ALTON, G.G.; JONES, L.M.; ANGUS, R.D.; VERGER, J.M. Techniques for the brucellosis laboratory. Paris: Institut National de la Recherche Agronomique, 1988. 545p.

ANTUNES, J.M. A.P.; ALLENDORF, S.D.; APPOLINÁRIO, C.M. et al. Serology for Brucella abortus in cart horses from an urban area in Brazil. Arq. Bras. Med. Vet. Zootec. v.65, p.619-621, 2013.

CHAVES, D.P.; BRITO, D.R. B.; SANTOS, A.C.G. et al. Soroprevalência de mormo, anemia infecciosa equina e brucelose do cavalo baixadeiro. Rev. Bras. Cienc. Vet., v.22, p.39$42,2015$. 
DIAS, J.A.; MÜLLER, E.E.; DIAS, R.A. et al. Situação epidemiológica da brucelose bovina no estado do Paraná. Arq. Bras. Med. Vet. Zootec., v.61, p.66-76, 2009.

DORNELES, E.M.S.; FERNANDES, L.G.; SANTANA, J.A. et al. Anti-Brucella abortus antibodies in free-ranging equids from Mossoró, Rio Grande do Norte, Brazil. Semina Cienc. Agrárias, v.34, p.1281-1286, 2013.

FURQUIM, M.E.C.; SOUZA, M.A.; MAGALHÃES, L.F. et al. Investigação da brucelose em equídeos abatidos em frigorífico exportador. Vet. Not., v.18, p.45-50, 2012.

JUNQUEIRA JÚNIOR, D.G.; DORNELES, E.M.S.; GONÇALVES, V.S.P. et al. Brucellosis in working equines of cattle farms from Minas Gerais state, Brazil. Prev. Vet. Med., v.121, p.380-385, 2015.
MARVULO, M.F.V.; FERREIRA, F.; DIAS, R.A. et al. Situação epidemiológica da brucelose bovina no estado do Rio Grande do Sul. Arq. Bras. Med. Vet. Zootec., v.61, p.93-102, 2009.

NIELSEN, K.; GALL, D.; JOLLEY, M. et al. A homogeneous fluorescence polarization assay for detection of antibody to Brucella abortus. $J$. Immunol. Methods, v.195, p.161-168, 1996.

RIBEIRO, M.G.; MOTTA, R.G.; ALMEIDA, C.A.S. Brucelose equina: aspectos da doença no Brasil. Rev. Bras. Reprod. Anim., v.32, p.83-92, 2008.

SOARES, C.P.O.C.; SILVA-JÚNIOR, F.F.; TELES, J.A.A. et al. Prevalência da Brucella spp em humanos. Rev. Latinoam. Enferm., v.23, p.919-926, 2015.

THRUSFIELD, M. Veterinary epidemiology. 3.ed. Oxford: Balckwell Science, 2005. 610 p. 